\title{
Influence of air temperature and velocity on performances of piglets weaned at 3 weeks
}

\author{
J. I.E DIVIDICH ( $\left.{ }^{(}\right)$, A. AUMAITRE $\left({ }^{1}\right)$ et P. BERBIGIER ${ }^{\left({ }^{2}\right)}$ \\ (1) Station de Recherches sur l'Elevage des Porcs, \\ I.N.R.A.-C.N.R.Z., $7835^{\circ}$ Jouy-en-Josas (France) \\ (2) Station de Bioclimatologie, \\ 1.N.R.A., route de Saint-Cyr, 78000 Versailles (France)
}

Iwo experiments were carried out in order to study the influence of tempcrature (trial i) and air velocity (trial 2) on the performances of piglets weaned at 22 days, on an average, and raised for 6 weeks (from 22 to 64 days of age) in a 1 tiers battery. The piglets were kept in groupsof 6 on an area of $0,24 \mathrm{~m}^{2}$ per animal and were fed ad libitum.

Trial I was divided into 2 parts:

a) comparison of performances obtained at $3^{\circ}$ and $25^{\circ} \mathrm{C}\left(4^{8} \times 2\right.$ piglets);

b) comparison of performances obtained at 20 and $25^{\circ} \mathrm{C}(48 \times 2$ piglets).

The group reared at $25^{\circ} \mathrm{C}$ constituted the control group for comparison of the 3 treatments. Two diets containing 4 and 9 per cent copra oil were used. Considering the overall period of measurements, the growth rate $(\mathrm{g} / \mathrm{d})$, feed intake $(\mathrm{g} / \mathrm{d})$ and feed conversion ratio decreased linearly with the temperature increase, i.e. 433,655 and $\mathrm{I} .5 \mathrm{I}$, respectively at $20^{\circ} \mathrm{C} ; 388,579$ and $\mathrm{I} .49$. at $25^{\circ} \mathrm{C} ; 374,54^{8}$ and 1.45 at $3^{\circ}{ }^{\circ} \mathrm{C}$. Growth rates obtained at 20 and $30^{\circ} \mathrm{C}$ were significantly different $(\mathrm{P}<0.01)$. At $3^{\circ}{ }^{\circ} \mathrm{C}$, the feed conversion ratio was 25 per cent $(\mathrm{P}<0.10)$ lower than at $20^{\circ} \mathrm{C}$ during the second week of the trial and I I per cent lower during the 3 rd and 4 th weeks. The rise in the energy level of the diet did not significantly affect the growth performance and feed intake of the animals. Neither the air temperature nor the copra oil content of the diets had any significant effect on the apparent digestibility of the energy of the diets.

Trial 2 was made on 96 piglets distributed into 2 groups and placed in 2 compartments with similar room temperature $\left(26^{\circ} \mathrm{C}\right.$ summer, no heating). The air velocity was constant (Io $\left.\mathrm{cm} . \mathrm{s}^{-1}\right)$. in one of the compartments; in the other it was increased to $40 \mathrm{~cm} . \mathrm{s}^{-1}$ between $10.00 \mathrm{a} . \mathrm{m}$. and 4.oo p.m.

For the whole period of measurements, a temporary increase in air velocity during the day had no marked effect either on growth rate $(397$ versus $379 \mathrm{~g} / \mathrm{d})$, feed intake $(604$ versus $59 \mathrm{I} \mathrm{g} / \mathrm{d}$ ) or feed conversion ratio ( 1.54 versus $1.6 I$ ).

\section{Composition of pig manure : Influence of the type of management}

\author{
Michèle HF́DUtiT ( $\left.{ }^{(}\right)$, J. L. ROUSTAN, A. AUMAITRE et Michèle SEGUIN (2) \\ (1) GIDA-I.T.P., I 49, me de Bercy, 75579 Paris Cedex I2 \\ (2) Station de Recherches sur l'Elevage des Porcs \\ I.N.R.A.-C.N.R.Z., $7835^{\circ}$ Jouy-en-Josas (France)
}

An investigation was made to ascertain the agricultural value of whole pig manure. A proximate chemical analysis was performed to measure $\mathrm{NTK}, \mathrm{P}_{2} \mathrm{O}_{5}, \mathrm{~K}_{2} \mathrm{O}$ and trace elements in 26 samples.

Among the samples collected in storage pits, a high correlation was found between dry matter content and NTK and $\mathrm{P}_{2} \mathrm{O}_{5}$ concentration.

NTK $(\mathrm{g} / 1)=0.53$ (DM p. cent) $+3.16 \quad r=+0.80$

$\mathrm{P}_{2} \mathrm{O}_{5}(\mathrm{~g} / \mathrm{l})=0.7 \quad(\mathrm{DM}$ p. cent $)+\mathrm{J} .2 .5 \quad r^{2}=+0.84$ 